\title{
Digital Technologies in Education 4.0. Does it Enhance the Effectiveness of Learning?
}

\section{A Systematic Literature Review}

https://doi.org/10.3991/ijim.v15i04.20291

Muhammad Imran Qureshi $(\bowtie)$

Universiti Teknikal Malaysia Melaka, Malaysia

qureshi@utem.edu.my

Nohman Khan

Universiti Kuala Lumpur, Kuala Lumpur, Malaysia

Hamad Raza

Universiti Teknologi Malaysia (UTM), Johor Bahru, Malaysia

Amina Imran, Fadillah Ismail

Universiti Tun Hussein Onn Malaysia, Parit Raja, Malaysia

\begin{abstract}
Over the past decade, digitalization shapes the overall educational structure worldwide, with the attention received from practitioners, researchers, and policymakers for educational development. Digital technologies are bringing massive changes across education, skills, and employment. These changes mirror how technology is increasingly central to education 4.0. Digital technologies are expanding beyond innovative and less traditional techniques of teaching and learning via education collaboration. However, the present study will explore the research conducted on digital technologies and education. Data is selected from the Scopus database reputed journals. The final 47 studies are chosen for the review process using PRISMA statement 2015, and bibliometric analysis is done to find the occurrence of keywords. The findings of the study are strengthening the value of educational growth and development of high-tech skills. Education's Future focuses on digital technologies, and the traditional modes of education will be replaced entirely.
\end{abstract}

Keywords - Digital Technologies, Digital Transformation, E-Learning, Education, Information Management, Digital Education, and Artificial Intelligence.

\section{$1 \quad$ Introduction}

Over the past decade, digitalization shapes the overall educational structure worldwide, with the attention received from practitioners, researchers, and policymakers for educational development. The rapid advancement of technology's digitalization in education is not influenced; other sectors are also changing [1]. Industry revolution 
4.0 is transforming the living and working standards of the planet; many conventional educational styles and learning methods are outdated. Digital education penetrates and helps educate from distance to door [2]. The industrial revolution in other sectors is also dependent on the educational structure to improve the industry's skills. The establishment of the educational sector is a fundamental part of the industrial revolution [3]. The education sector has an opening to provide a more significant objective in communication conditions, appropriate knowledge, and deployment of understanding. Information will be set free and easily accessible; nevertheless, the perspective and understanding of knowledge will be essential to unraveling innovative learning methods. Conventional school room education will now have to convert to allow all approaches and way of life learning, distance learning, and practical learning [4].

Education philosophy does not consist of composed, giant physical availability structures, devices, and educational development developed on psychological buildings. The purpose of education in the modern world is shifting on technological learning and usability. An individual will be considered skillful, learning the new technology in which time. A skill that is working today that might not be useful tomorrow is the conceptualization of education 4.0 [5]. Future learning will be loaded with digital technology that is simple, economical, and efficient. Because of that, education administration and learning procedure must be endorsed by aggressive improvement, exceptional service systems, determination, exclusive aptitudes, skill to leading data and info resources, constant transformation and development, alignment to excellence, consummation, and belief [6].

The fourth industrial revolution brings the paradigm shift in educational policies and reforms in many worlds. Developed nations adapt the technological advancement regularly, fill the required skills gap, and open the doors of new resources. The case of an underdeveloped nation is very much different due to enough ability, political incompetence, and long processing policies to implement the digitalization processes [7]. According to Roodt \& Koen, (2020) fourth Industrial Revolution and Industry 4.0 technologies will present the enormous wealth creation opportunity in our planet's history. The technology leaders and digital entrepreneurs will be grabbing the opportunity by advancement in technology.

The current study is designed to evaluate the overall progress of research on digital technologies in education 4.0. The main agenda is to find the direction and improvement of research related to the educational structure and change in digital technologies' learning process. The recent development of digital technologies in many fields attracts researchers to improve education quality using these resources. Fast speed internet, high-performance digital devices, and machine learning processes create a vacuum of human capital skills [9]. The current study will review the literature and find the classification, settings, procedures, and methodology to overview the significance of literature on digital technologies and education 4.0. The other scope of the study is to find the gap and limitations of research on the area. 


\section{Materials and Methods}

In reporting the results and developing the research framework, authors worldwide are using the PRISMA statement 2015. The systematic literature review (SLR) is a guide to enhance the reviews and meta-analysis [10]. The PRISMA statement template explains the overall research process for the selection and rejection of articles in this SLR. This SLR base study is limited to published literature on the topic of digital technologies and education 4.0. The databases Scopus is using for the literature extraction. The keywords are used "Digital technologies" AND "Education" in the search bar. The database's total results shown 3378, for more purification of the effects the internal search option uses. In the inner search, the keyword education 4.0, the databases shrink the results to 112. For the other process, subjects are selected for the current study, computer sciences, Engineering, Business, Management and Accounting, Medicine, Environmental Science, Arts and Humanities, Economics, Econometrics and Finance, Psychology, Health Professions, Multidisciplinary are selected. The results are narrow down to 105 .

Further on only articles, publishing stage final published paper, language English is chosen in the database. Results are narrowed down to 49, and after removing the duplication, and irrelevant literature, the final 47 studies are included for the review. Figure 1 is showing the detailed process of data selection.

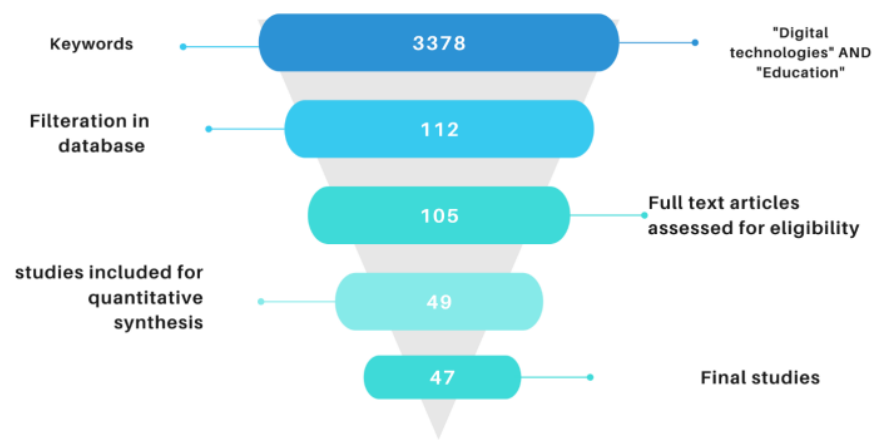

Fig. 1. PRISMA statement 2015

\section{$3 \quad$ Results}

\subsection{Descriptive analysis}

The study is not focusing on the specific time frame for the articles. The year-wise distribution's primary purpose is to understand the number of publications in a year selected and fulfill the review criteria. Figure 2 shows the year base graph of literature. The year 2019 contributing the highest number with sixteen articles. The year 2018 is second in the list with thirteen research papers on digital technologies, the 
year 2020 added ten studies. So, the number of contributions in the recent past is high rather than in the past. Figure 2 is showing the detailed information of articles selected from different years.
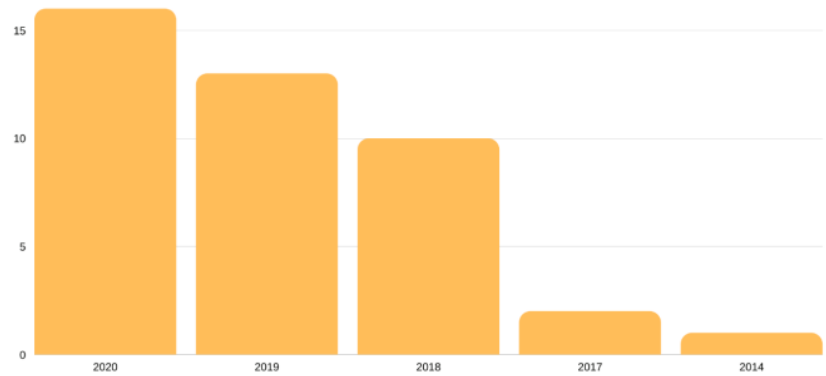

Fig. 2. Distribution of literature year base publications

Furthermore, the journal base publication analysis is conducted for the current study and finds that ten conference papers are selected for the current study. Second, most reviews are select from the Technological Forecasting and Social Change with 3 in number. Gradually the name of the studies is going down for the current study. Journal of Information Systems Education contributes, has added two articles. Figure 3 is showing the results of the research article selected from each journal.

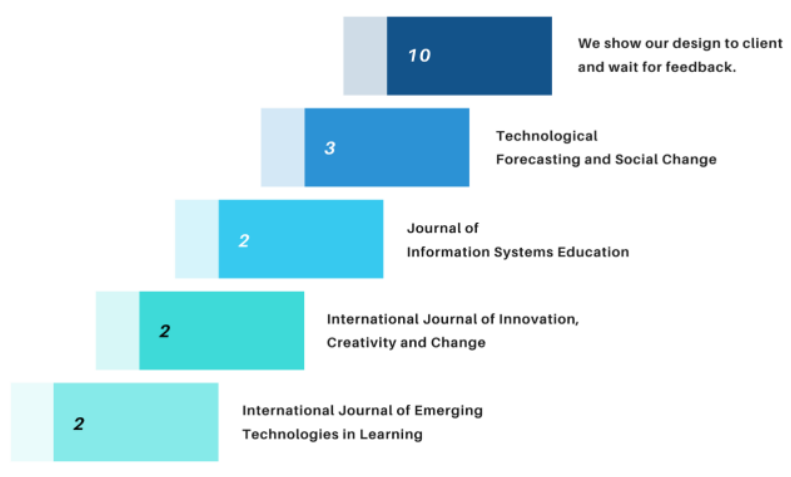

Fig. 3. Distribution of literature journal base publications

The following cluster of keywords inside figure 4 demonstrates either one that subject has been continuously discussed in the investigated articles over the entire considered time, the keywords' be an average of publication year, or that the issue was of interest and published in the journal average. Thus, part of this group is keywording, such as digital technologies, digital transformation, e-learning, education, information management, digital education, and artificial intelligence. The result confirms the 
importance of all digital technologies, which require continuous inquiries to reach common frameworks that improve education.

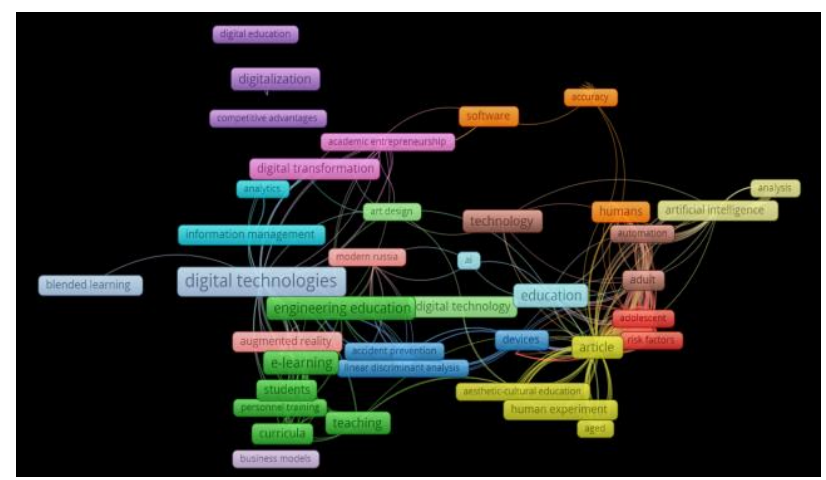

Fig. 4. Keywords used in published literature

\subsection{Classification}

Literature from selected criteria is classifying according to the area of literature, segment, setting, and methodology. Industrial revolution 4.0 is emphasizing the usage of fast speed internet that helps penetration of digital technologies. The utilization of technologies in education is opening new doors of learning and optimization of resources. Large-scale infrastructures are moving into a room and a digital device [11]. The below section is explaining the detailed literature classification accordingly.

\subsection{Digital technologies}

The current social-economic structure is facing resistance to the implementation of education in 4.0. The first step toward implementing revolution 4.0 is a legal framework and normative provision of the digital world. Government regulators have enough interest; they are practical implementors of digital technologies [12]. Digital technologies adaptation in the developed part of the world is more regular and efficient due to healthy learning and adaptation structure, while in the case of underdeveloped and developed regions, many implementation and regulation issues occur [13]. However, recent studies argue that consistent development and technology enlargement create space for the digital transformation of education. Given the demographic position and enlightened robotics, significant education needs can be likely soon in individual and adaptable systems using digital technologies [14]. According to Hrtoňová et al. (2015), in the era of IR 4.0, digital technologies are becoming an integral part of society; educational development and learning are the vision of the current world with digitalization.

In the modern world, from primary school children to higher education, students are familiar with digital devices like smartphones, tablets, and laptops. Usually, they are using these devices for communication and entertainment purposes. However, 
changing world requirement is more towards learning and educating with these devices for the students. Understanding these devices is challenging for trainers and educators, working for a long time. Zeehan et al., (2020) study findings show that educators' training is challenging for new technologies. The study's recommendations also suggest that educators have yet to optimize digital technologies in their educational practice to develop education skills in digital technologies.

Table 1. Classification and details of digital technologies

\begin{tabular}{|c|c|c|c|c|c|c|}
\hline Authors & Year & Source title & Title & Methodology & Segment & Settings \\
\hline $\begin{array}{l}\text { Twyman } \\
\text { J.S. }\end{array}$ & 2014 & $\begin{array}{l}\text { Revista Mexi- } \\
\text { cana de Analisis } \\
\text { de la Conducta }\end{array}$ & $\begin{array}{l}\text { Envisioning education } \\
\text { 3.0: The fusion of behav- } \\
\text { ior analysis, learning } \\
\text { science and technology } \\
\text { [Vislumbrando la edu- } \\
\text { cación 3.0: La fusión del } \\
\text { análisis de la conducta, la } \\
\text { ciencia Del aprendizaje y } \\
\text { la tecnología] }\end{array}$ & Quantitative & $\begin{array}{l}\text { Digital envi- } \\
\text { ronments }\end{array}$ & $\begin{array}{l}\text { University } \\
\text { environ- } \\
\text { ments }\end{array}$ \\
\hline $\begin{array}{l}\text { Twyman } \\
\text { J.S. }\end{array}$ & 2014 & $\begin{array}{l}\text { Revista Mexi- } \\
\text { cana de Analisis } \\
\text { de la Conducta }\end{array}$ & $\begin{array}{l}\text { Envisioning education } \\
\text { 3.0: The fusion of behav- } \\
\text { ior analysis, learning } \\
\text { science and technology } \\
\text { [Vislumbrando la edu- } \\
\text { cación 3.0: La fusión del } \\
\text { análisis de la conducta, la } \\
\text { ciencia Del aprendizaje y } \\
\text { la tecnología] }\end{array}$ & Quantitative & $\begin{array}{l}\text { Digital envi- } \\
\text { ronments }\end{array}$ & $\begin{array}{l}\text { University } \\
\text { environ- } \\
\text { ments }\end{array}$ \\
\hline $\begin{array}{l}\text { Herout, L; } \\
\text { Jirsakova, J }\end{array}$ & 2017 & $\begin{array}{l}\text { 10th interna- } \\
\text { tional confer- } \\
\text { ence of educa- } \\
\text { tion, research, } \\
\text { and innovation } \\
\text { (iceri2017) }\end{array}$ & $\begin{array}{l}\text { THE use of digital tech- } \\
\text { nologies in the education- } \\
\text { al environment in the } \\
\text { czech republic }\end{array}$ & $\begin{array}{l}\text { Quantitative } \\
\text { and qualita- } \\
\text { tive }\end{array}$ & $\begin{array}{l}\text { Information } \\
\text { and communi- } \\
\text { cation tech- } \\
\text { nologies }\end{array}$ & $\begin{array}{l}\text { Education } \\
\text { system }\end{array}$ \\
\hline Network T. & 2019 & \begin{tabular}{|l|} 
International \\
Journal of \\
Information and \\
Education \\
Technology \\
\end{tabular} & $\begin{array}{l}\text { The school library roles } \\
\text { in information services } \\
\text { through mainstreaming to } \\
\text { enhance } 21 \text { st-century } \\
\text { learning skills }\end{array}$ & Qualitative & $\begin{array}{l}\text { Digital infor- } \\
\text { mation ser- } \\
\text { vices }\end{array}$ & $\begin{array}{l}\text { Library } \\
\text { Service } \\
\text { provision }\end{array}$ \\
\hline $\begin{array}{l}\text { Tetep, } \\
\text { Suparman } \\
\text { A. }\end{array}$ & 2019 & \begin{tabular}{|l|} 
International \\
Journal of \\
Recent Tech- \\
nology and \\
Engineering \\
\end{tabular} & $\begin{array}{l}\text { Students' digital media } \\
\text { literacy: Effects on the } \\
\text { social character }\end{array}$ & Quantitative & Media literacy & University \\
\hline $\begin{array}{l}\text { Zeehan F., } \\
\text { Alias R.A., } \\
\text { Tasir Z. }\end{array}$ & 2020 & $\begin{array}{l}\text { Universal } \\
\text { Journal of } \\
\text { Educational } \\
\text { Research }\end{array}$ & $\begin{array}{l}\text { Discovering digital } \\
\text { technology training } \\
\text { challenges for future- } \\
\text { ready educator: A prelim- } \\
\text { inary study from a trainer } \\
\text { perspective }\end{array}$ & Qualitative & $\begin{array}{l}\text { Post- } \\
\text { secondary } \\
\text { education }\end{array}$ & Empirical \\
\hline $\begin{array}{l}\text { Tan S.W.B., } \\
\text { Narahari- } \\
\text { setti P.K., } \\
\text { Chin S.K., } \\
\text { Lee L.Y. }\end{array}$ & 2020 & $\begin{array}{l}\text { Journal of } \\
\text { Chemical } \\
\text { Education }\end{array}$ & $\begin{array}{l}\text { Simple Visual-Aided } \\
\text { Automated Titration } \\
\text { Using the Python Pro- } \\
\text { gramming Language }\end{array}$ & Experiment & $\begin{array}{l}\text { Scientists of } \\
\text { the Future }\end{array}$ & Experiment \\
\hline
\end{tabular}




\begin{tabular}{|c|c|c|c|c|c|c|}
\hline $\begin{array}{l}\text { Safiullin } \\
\text { M.R., } \\
\text { Akhmetshin } \\
\text { E.M. }\end{array}$ & 2019 & \begin{tabular}{|l|} 
International \\
Journal of \\
Engineering and \\
Advanced \\
Technology
\end{tabular} & $\begin{array}{l}\text { Digital transformation of } \\
\text { a university as a factor of } \\
\text { ensuring its competitive- } \\
\text { ness }\end{array}$ & Qualitative & $\begin{array}{l}\text { Network and } \\
\text { distance } \\
\text { learning }\end{array}$ & University \\
\hline $\begin{array}{l}\text { Molin L., } \\
\text { Godhe A.- } \\
\text { L., Lantz- } \\
\text { Andersson } \\
\text { A. }\end{array}$ & 2018 & $\begin{array}{l}\text { Cogent Educa- } \\
\text { tion }\end{array}$ & $\begin{array}{l}\text { Instructional challenges } \\
\text { of incorporating aspects } \\
\text { of critical literacy work in } \\
\text { digitalized classrooms }\end{array}$ & Qualitative & $\begin{array}{l}\text { Critical litera- } \\
\text { cy }\end{array}$ & $\begin{array}{l}\text { Digitalized } \\
\text { classroom }\end{array}$ \\
\hline $\begin{array}{l}\text { Molin L., } \\
\text { Godhe A.- } \\
\text { L., Lantz- } \\
\text { Andersson } \\
\text { A. }\end{array}$ & 2018 & $\begin{array}{l}\text { Cogent Educa- } \\
\text { tion }\end{array}$ & $\begin{array}{l}\text { Instructional challenges } \\
\text { of incorporating aspects } \\
\text { of critical literacy work in } \\
\text { digitalized classrooms }\end{array}$ & Qualitative & $\begin{array}{l}\text { Critical litera- } \\
\text { cy }\end{array}$ & $\begin{array}{l}\text { Digitalized } \\
\text { classroom }\end{array}$ \\
\hline $\begin{array}{l}\text { Rohlikova, } \\
\text { L }\end{array}$ & 2018 & \begin{tabular}{|l|} 
Divai 2018: \\
12th Interna- \\
tional Scientific \\
Conference on \\
Distance Learn- \\
ing in Applied \\
Informatics \\
\end{tabular} & $\begin{array}{l}\text { Flexible Forms of Learn- } \\
\text { ing as a Challenge for } \\
\text { Higher Education }\end{array}$ & Qualitative & $\begin{array}{l}\text { Online educa- } \\
\text { tion }\end{array}$ & University \\
\hline $\begin{array}{l}\text { Llata, JR; } \\
\text { Sancibrian, } \\
\text { R; Sarabia, } \\
\text { EG; Torre- } \\
\text { Ferrero, C; } \\
\text { Blanco, JM }\end{array}$ & 2018 & \begin{tabular}{|l|} 
Edulearn18: \\
10th Interna- \\
tional Confer- \\
ence on Educa- \\
tion and New \\
Learning Tech- \\
nologies
\end{tabular} & $\begin{array}{l}\text { Education Innovation in } \\
\text { Discrete-time Feedback } \\
\text { Control by using 3D- } \\
\text { Technologies }\end{array}$ & Qualitative & Teaching & $\begin{array}{l}\text { Students of } \\
\text { Engineering }\end{array}$ \\
\hline $\begin{array}{l}\text { Abukhousa, } \\
\text { E }\end{array}$ & 2019 & \begin{tabular}{|l|}
12 th interna- \\
tional confer- \\
ence of educa- \\
tion, research, \\
and innovation \\
(iceri 2019)
\end{tabular} & \begin{tabular}{|l|} 
Integration of Industry \\
4.0 Technologies with \\
Social and Behavioral \\
Analysis to Shape a \\
Smart Learning Experi- \\
ence in Higher Education
\end{tabular} & Quantitative & Big Data & $\begin{array}{l}\text { Higher } \\
\text { Education }\end{array}$ \\
\hline $\begin{array}{l}\text { Turcu, CO; } \\
\text { Turcu, CE }\end{array}$ & 2018 & $\begin{array}{l}\text { International } \\
\text { Journal of } \\
\text { Advanced } \\
\text { Computer } \\
\text { Science and } \\
\text { Applications }\end{array}$ & $\begin{array}{l}\text { Industrial Internet of } \\
\text { Things as a Challenge for } \\
\text { Higher Education }\end{array}$ & Qualitative & $\begin{array}{l}\text { Higher } \\
\text { Education }\end{array}$ & $\begin{array}{l}\text { Students, } \\
\text { Graduates }\end{array}$ \\
\hline
\end{tabular}

The recent development of digitalization in IR 4.0 changes the educational medium, and learning skills and working skills are also changing. The progress of digital technology offers an opportunity to provide students with appropriate learning synchronizes as "Scientists of the Future" who can develop knowledge at the line between different subjects [17]. Learning skills development due to digital devices and the Internet of Things (IoT) is easier for students and academicians due to digital resources' penetration in recent times. According to [18], currently, there is a skill gap of skills and required skills for the usability of digital devices and IOTs, which may expand in the potential if no action is carried. Higher education must adopt the most recent associated technologies, and IOTs adapt to the new ways to interact with machines and data. The worldwide socio-economic challenges put requirements on the 
21st Century higher education to utilize digital technologies and big data analytics to allow customized learning skills under value-added intelligent educational models. That enables a collaborative learning environment, where the academicians are selecting the best learning models for education. That is also connected with communities; here, they can advance the skills and cumulative knowledge. The development of the Industry 4.0 model simultaneously creates Control Computing, Big Data, the Internet of Things (IoT), Cyber-Physical Systems (CPS), and to integrate intelligent applications and adaptive services for smoother environments [19].

The combination of digital devices creating an easier way to enhance the teaching and learning environment easier. According to (2018), modern 3-D technologies provide a better learning experience that is computer control. Using 3-D technologies in teaching enhancing skills and new methods enable increasing employability potential for engineering studies/degrees and fostering future students' interest in them. The fourth industrial revolution (IR 4.0) is generally accepted as a digital technological innovation developing on the merging of Robotics, the Internet of Things, and the Internet of Services. These are creating students' abilities and skills due to these devices' availability commonly for the users. However, the education structure still has a gap of skills and literacy about these devices' usability in the learning process [20]. The transformation of how we look and do education has been an essential element in IR 4.0. Although digital technologies enable individual and self-learning models that reflect empowerment, users still need the skill and abilities to deal with these devices [21].

The digitalize enables to individual learn independently, still a lead that is challenging about critical learning. Digital technologies are contributing a significant impact on the learning process. Literature is always minimal to discuss the critical literacy of the students [22]. The digital technologies literature is significantly based on qualitative research, and Table 1 shows the details of literature classification, segment, procedure, and methodology used. Literature has enough studies from quantitative and review papers in the category of literature.

\subsection{Education 4.0}

The education 4.0 literature is included in the current study from published articles. According to the World Economic Forum (2009), education is based on composed physical structure, also consist of system and devices that are developing psychological composition. The construction of knowledge is like the building of housing societies, bridges, and roads. Developing education in the industrial revolution era 4.0 focuses on rationality and skills by disregarding ethics and confidence. The impact of IR 4.0 on education is the same as the other segments; now, the many educational policies and practices are no longer relevant. The Thailand government case study discusses the current research; the Thai government announced the system to adopt IR 4.0 for education purposes. Thai government uses online class sessions and video course materials available for the students online. The findings have shown the students and teachers [24]. The sustainable education system in industry revolution 4.0 is possible with fast speed internet and high user-end digital devices. Education 4.0 has 
an essential responsibility to deliver talented and marketable resources that can perform and fulfill the industry's demands. The blend learning model is one of the examples present to handle the potential harnessing digital technologies. Model is developed for students' online learning and self-directed learning awareness [25].

Table 2. Classification and details of education 4.0

\begin{tabular}{|c|c|c|c|c|c|c|}
\hline \begin{tabular}{|l|} 
Authors \\
\end{tabular} & Year & Source title & Title & Methodology & Segment & Settings \\
\hline $\begin{array}{l}\text { Sirucek, } \mathrm{P} ; \\
\text { Dzbankova, } \\
\mathrm{Z}\end{array}$ & 2018 & $\begin{array}{l}\text { 12th International } \\
\text { Days of Statistics and } \\
\text { Economics }\end{array}$ & $\begin{array}{l}\text { Quo Vadis, Educa- } \\
\text { tion 4.0? }\end{array}$ & Qualitative & $\begin{array}{l}\text { Digital } \\
\text { Society }\end{array}$ & $\begin{array}{l}\text { Education } \\
\text { System }\end{array}$ \\
\hline $\begin{array}{l}\text { Volkova, I; } \\
\text { Miklosikova, } \\
\text { M; Malcik, } \\
\text { M }\end{array}$ & 2018 & $\begin{array}{l}12 \text { th International } \\
\text { Technology, Educa- } \\
\text { tion, and Develop- } \\
\text { ment Conference } \\
\text { (inted) }\end{array}$ & $\begin{array}{l}\text { Misconceptions in } \\
\text { Education of Phys- } \\
\text { ics among Czech } \\
\text { Secondary School } \\
\text { Graduates }\end{array}$ & Quantitative & $\begin{array}{l}\text { Secondary } \\
\text { School } \\
\text { Students }\end{array}$ & University \\
\hline $\begin{array}{l}\text { Matching, R; } \\
\text { Pfeiffer, D; } \\
\text { Gawin, A; } \\
\text { Gawin, P; } \\
\text { Steiner, M; } \\
\text { Streli, L }\end{array}$ & 2018 & $\begin{array}{l}2018 \text { IEEE Frontiers } \\
\text { in Education Confer- } \\
\text { ence (FIE) }\end{array}$ & $\begin{array}{l}\text { Enhancing Stanford } \\
\text { Design Thinking for } \\
\text { kids with Digital } \\
\text { Technologies A } \\
\text { Participatory Action } \\
\text { Research Approach } \\
\text { to Challenge-based } \\
\text { Learning }\end{array}$ & Content Analysis & $\begin{array}{l}\text { Future } \\
\text { Classroom }\end{array}$ & Workshops \\
\hline Anaraki F. & 2018 & ABAC Journal & $\begin{array}{l}\text { The effectiveness of } \\
\text { blended learning: a } \\
\text { case study }\end{array}$ & Qualitative & $\begin{array}{l}\text { Schools and } \\
\text { Universities }\end{array}$ & $\begin{array}{l}\text { Digitalized } \\
\text { Classroom }\end{array}$ \\
\hline $\begin{array}{l}\text { Badaruddin, } \\
\text { Noni N., } \\
\text { Jabu B. }\end{array}$ & 2019 & Asian EFL Journal & $\begin{array}{l}\text { The potential of ICT } \\
\text { in Blended Learning } \\
\text { Model toward } \\
\text { Education } 4.0 \text { Need } \\
\text { Analysis-based } \\
\text { Learning Design for } \\
\text { ELT }\end{array}$ & Quantitative & $\begin{array}{l}\text { Higher } \\
\text { Education }\end{array}$ & $\mid \begin{array}{l}\text { Students } \\
\text { and Teach- } \\
\text { ers }\end{array}$ \\
\hline $\begin{array}{l}\text { Ismail, NAS; } \\
\text { Arifin, KT; } \\
\text { Alias, E; } \\
\text { Tan, JK; } \\
\text { Damanhuri, } \\
\text { MHA; } \\
\text { Karim, NA; } \\
\text { Goon, JA; } \\
\text { Zubri, ZJM; } \\
\text { Makpol, S; } \\
\text { Yusof, YAM } \\
\end{array}$ & 2018 & $\begin{array}{l}\text { Edulearn18: 10th } \\
\text { International Confer- } \\
\text { ence on Education } \\
\text { and New Learning } \\
\text { Technologies }\end{array}$ & $\begin{array}{l}\text { Learning Medical } \\
\text { Biochemistry } \\
\text { through Interactive } \\
\text { Learning }\end{array}$ & Quantitative & $\begin{array}{l}\text { Teaching } \\
\text { and Learn- } \\
\text { ing }\end{array}$ & $\begin{array}{l}\text { Medical } \\
\text { Biochemis- } \\
\text { try }\end{array}$ \\
\hline $\begin{array}{l}\text { Cheglakova, } \\
\text { LS; } \\
\text { Devetyarova, } \\
\text { IP; Agalako- } \\
\text { va, OS; } \\
\text { Kolesova, } \\
\text { YA }\end{array}$ & 2020 & $\begin{array}{l}\text { international journal } \\
\text { for quality research }\end{array}$ & $\begin{array}{l}\text { marketing strategy } \\
\text { of quality manage- } \\
\text { ment during reor- } \\
\text { ganization of re- } \\
\text { gional universities } \\
\text { in the process of } \\
\text { modernization of } \\
\text { education in the } \\
\text { conditions of re- } \\
\text { gion's transition to } \\
\text { industry } 4.0\end{array}$ & quantitative & $\begin{array}{l}\text { marketing } \\
\text { strategy }\end{array}$ & $\begin{array}{l}\text { regional } \\
\text { universities }\end{array}$ \\
\hline
\end{tabular}




\begin{tabular}{|c|c|c|c|c|c|c|}
\hline $\begin{array}{l}\text { Turcu C.O., } \\
\text { Turcu C.E. }\end{array}$ & 2018 & $8 \begin{array}{l}\text { International Journal } \\
\text { of Advanced Com- } \\
\text { puter Science and } \\
\text { Applications }\end{array}$ & $\begin{array}{l}\text { Industrial Internet of } \\
\text { Things as a Chal- } \\
\text { lenge for Higher } \\
\text { Education }\end{array}$ & Qualitative & \begin{tabular}{|l} 
Earning and \\
Acquiring \\
New Skills
\end{tabular} & $\begin{array}{l}\text { Higher } \\
\text { Education }\end{array}$ \\
\hline $\begin{array}{l}\text { Mulyasana } \\
\text { D. }\end{array}$ & 2019 & $\begin{array}{l}\text { International Journal } \\
\text { of Innovation, Crea- } \\
\text { tivity, and Change }\end{array}$ & $\begin{array}{l}\text { The Impact of the } \\
\text { Industrial Revolu- } \\
\text { tion Flows } 4.0 \text { on } \\
\text { Competitiveness, } \\
\text { Policy, and Stand- } \\
\text { ards of Education } \\
\text { Quality }\end{array}$ & Qualitative & $\begin{array}{l}\text { Psychologi- } \\
\text { cal Struc- } \\
\text { tures }\end{array}$ & $\begin{array}{l}\text { Devices and } \\
\text { Systems }\end{array}$ \\
\hline $\begin{array}{l}\text { Ramirez- } \\
\text { Mendoza, } \\
\text { RA; Mo- } \\
\text { rales- } \\
\text { Menendez, } \\
\text { R; Iqbal, H; } \\
\text { Parra- } \\
\text { Saldivar, R }\end{array}$ & 2018 & $\begin{array}{l}\text { Proceedings of } 2018 \\
\text { IEEE Global Engi- } \\
\text { neering Education } \\
\text { Conference (Educon) } \\
\text {-Emerging Trends } \\
\text { and Challenges of } \\
\text { Engineering Educa- } \\
\text { tion }\end{array}$ & $\begin{array}{l}\text { Engineering Educa- } \\
\text { tion 4.0-Proposal for } \\
\text { a new Curricula }\end{array}$ & Qualitative & $\begin{array}{l}\text { Social } \\
\text { Environ- } \\
\text { ments }\end{array}$ & University \\
\hline
\end{tabular}

Sustainable education 4.0 is impossible without the involvement and accessibility of the Internet of Things (IoT) in industrial revolution 4.0, where machines are an integral part of social and economic development [26]. According to Khan, (2018), the Internet of Things (IoT) in the industry (so-called Industrial Internet of Things, shortly (IIoT) and the requirements for higher education in the times of the fourth industrial revolution. The concept is showing the importance of devices in process 4.0. The study's findings showed that the skill gap between digital technologies and IOTs widens if the students and teachers cannot adopt education 4.0. The IR 4.0 concerning the marketable graduate and skills required, still gap is long, and many higher education reforms are essential for improving education and education system. Digital technologies in industrial revolution 4.0 visioning towards the digital society using the education progressiveness [28]. However, literature is specifically highlighted the learning outcomes using digital technologies in students, according to Goswami et al., (2017) study showing that the learning outcomes determine integrated performance through formative performance and reflection. They are given a chance to improve on their account before the end of the final examination. The study's findings showed that students learn skills using interactive technologies and mediums; they learn quickly and effectively.

However, the young generation should be prepared for the adaptation of technology and advance education learning in the coming years; education 4.0 is not changing the learning structure, the sources of knowledge are outdated now [30]. Digital competency is a requirement for the future world; digital competency acquisition is an essential component of education 4.0. Develop digital competencies requirements to be supported by individual and community facilities that take time to grow up. Education 4.0 is in this regard; many nations are applying digital educational reforms for robust academic structure [31]. Furthermore, Education 4.0 allows students and teachers to learn, including consistency, ensuring sustainability, and developing cooperation. Table 2 shows the literature classification, segment, procedure, and method- 
ology used in the published articles. In the previous section, literature is used as a qualitative method; this literature classification consists of quantitative.

\subsection{Digital transformation}

Digital transformation and artificial intelligence are the third primary classification of literature related to Education 4.0. The conventional method of education from schools to higher education level is rapidly transforming into the digital mode of learning, and the cost of infrastructure installation is higher at once; later, the outcomes are valuable. The education system is completely changed and shaped due to the transformation of traditional industry by digital technologies [32]. Educational institutes played a vital role before the education 4.0 model, and now the part of education is more significant due to the importance of skill requirement. Higher education universities need to digitalize and use digital communications for learning and create more distance learning channels [33]. The digital transformation is not more comfortable for the under-developing nations; developed nations are smoothly designing education 4.0 models to optimize learning. Teaching is challenging for teachers due to the rapid development of digital technologies like robots and artificial intelligence in education. The education sector is influenced as only skilled, highly trained, and educated workers are needed. IR4.0 technologies have formed new jobs in meeting the requirements of the current marketplace, as such new customer services and distinctive goods will be announced [34]

The recent literature emphasizes that teachers' education curriculum level and skills are not enough that need improvement. That leads to the new digital technologies related to education curriculum in current circumstances, fitting with the need for technology changes. [35]. According to Qureshi, Khan, Muhammad, et al., (2020) the extent to which teachers accept digital technology education in their teaching practice has long been in the focus of education and learning. Future teaching is wholly based on digital mediums and devices; avoiding digitalization is not possible at this point. Artificial Intelligence is supported by the Industrial Revolution 4.0 to transform the volatile digital strategies and challenge the whole world. Effectual use of digital learning settings in academic putting involves an advantage in answering many critical techno-social concerns jointly. Leiner et al., (2018) revealed that policies and predilections of digital sources fluctuate significantly among teachers and students. Teachers choose to follow less developed or formed systems where students prefer the growing technologies in the cooperative model. In the future perspective, the learning and continuous learning model are more useful for teachers due to the ongoing digital transformation process. 
Table 3. Classification and details of digital transformation

\begin{tabular}{|c|c|c|c|c|c|c|}
\hline Authors & Year & Source title & Title & Methodology & Segment & Settings \\
\hline $\begin{array}{l}\text { Vodenko } \\
\text { K.V., } \\
\text { Lyausheva } \\
\text { S.A. }\end{array}$ & 2020 & $\begin{array}{l}\text { Journal of Intellectual } \\
\text { Capital }\end{array}$ & $\begin{array}{l}\text { Science and Educa- } \\
\text { tion in form 4.0: } \\
\text { Public Policy and } \\
\text { Organization Based } \\
\text { on Human and } \\
\text { Artificial Intellectual } \\
\text { Capital }\end{array}$ & Quantitative & $\begin{array}{l}\text { Science and } \\
\text { Education }\end{array}$ & Universities \\
\hline $\begin{array}{l}\text { Joseph G.V., } \\
\text { Thomas } \\
\text { K.A. }\end{array}$ & 2020 & $\begin{array}{l}\text { Test Engineering and } \\
\text { Management }\end{array}$ & $\begin{array}{l}\text { The volatility of } \\
\text { digital technology- } \\
\text { enabled learning } \\
\text { through social me- } \\
\text { dia: Educators" } \\
\text { apprehensions }\end{array}$ & Quantitative & $\begin{array}{l}\text { Digital } \\
\text { Learning } \\
\text { Environ- } \\
\text { ments }\end{array}$ & Academic \\
\hline $\begin{array}{l}\text { Scherer R., } \\
\text { Siddiq F., } \\
\text { Tondeur J. }\end{array}$ & 2019 & $\begin{array}{l}\text { Computers and } \\
\text { Education }\end{array}$ & $\begin{array}{l}\text { The Technology } \\
\text { Acceptance Model } \\
\text { (TAM): A Meta- } \\
\text { Analytic Structural } \\
\text { Equation Modeling } \\
\text { Approach to Ex- } \\
\text { plaining Teachers' } \\
\text { Adoption of Digital } \\
\text { Technology in } \\
\text { Education }\end{array}$ & Quantitative & Classrooms & Empirical \\
\hline $\begin{array}{l}\text { Sirotkina, N; } \\
\text { Mishchen- } \\
\text { ko, V; } \\
\text { Greshonkov, } \\
\text { A; Kamin- } \\
\text { skiy, S; } \\
\text { Kazartseva, } \\
\text { A }\end{array}$ & 2019 & $\begin{array}{l}\text { EDUCATION } \\
\text { EXCELLENCE AND } \\
\text { INNOVATION } \\
\text { MANAGEMENT } \\
\text { THROUGH VISION } \\
2020\end{array}$ & $\begin{array}{l}\text { Challenges and } \\
\text { Opportunities of } \\
\text { Human Potential in } \\
\text { the Conditions of } \\
\text { Technological } \\
\text { Breakthrough }\end{array}$ & Qualitative & education & $\begin{array}{l}\text { school } \\
\text { education }\end{array}$ \\
\hline $\begin{array}{l}\text { Ismail A.A., } \\
\text { Hassan R. }\end{array}$ & 2019 & $\begin{array}{l}\text { Journal of Technical } \\
\text { Education and Train- } \\
\text { ing }\end{array}$ & $\begin{array}{l}\text { Technical Compe- } \\
\text { tencies in Digital } \\
\text { Technology towards } \\
\text { Industrial Revolution } \\
4.0\end{array}$ & Quantitative & $\begin{array}{l}\text { Education } \\
\text { Sector }\end{array}$ & $\begin{array}{l}\text { Polytech- } \\
\text { nics }\end{array}$ \\
\hline $\begin{array}{l}\text { Safiullin } \\
\text { M.R., } \\
\text { Akhmetshin } \\
\text { E.M. }\end{array}$ & 2019 & $\begin{array}{l}\text { International Journal } \\
\text { of Engineering and } \\
\text { Advanced Technolo- } \\
\text { gy }\end{array}$ & $\begin{array}{l}\text { Digital Transfor- } \\
\text { mation of a Universi- } \\
\text { ty as a factor of } \\
\text { Ensuring its Compet- } \\
\text { itiveness }\end{array}$ & Qualitative & $\begin{array}{l}\text { Network and } \\
\text { distance } \\
\text { learning }\end{array}$ & University \\
\hline $\begin{array}{l}\text { Durakbasa, } \\
\text { N; Bas, G; } \\
\text { Bauer, J }\end{array}$ & 2018 & $\begin{array}{l}\text { XXIII International } \\
\text { Conference on Man- } \\
\text { uFacturing (Manufac- } \\
\text { turing 2018) }\end{array}$ & $\begin{array}{l}\text { Implementing Edu- } \\
\text { cation Vision in the } \\
\text { Context of Industry } \\
4.0\end{array}$ & Qualitative & $\begin{array}{l}\text { Education } \\
\text { System }\end{array}$ & Universities \\
\hline
\end{tabular}

However, the findings of literature showing in a study included in the current review; artificial intellectual capital can be used to build human effectiveness and competitiveness to determine the education system and science and respond to potential modern-day challenges. Findings of a study recommended using the advanced model of the structure of science and education in form 4.0 centered on human and artificial intellectual capital [38]. However, some researchers believe that the crucial factor is 
human: skillful human resource who can use digital technologies and adapt quickly, using innovative technologies. Without the talented human capital, the corporate world cannot progress and enhance the growth: digital business models, industry 4.0 robots, advanced data, artificial intelligence, and virtual reality. Education 4.0 is a critical element for developing skillful human capital [39]. The digital transformation is significantly dependent on education4.0 due to the skills that are required in the industry. The digital transformation data is analyzed from the many authors; they used qualitative and quantitative research methodologies. Table 3 is showing the classification, setting, procedure, and methods of literature used.

\section{Discussion and Conclusion}

The industry revolution 4.0 brings rapid changes in many industries worldwide and will continue disrupting drive and education. The current study idea evaluates the research progress on this critical area and analyzes the literature direction about education 4.0. The selection of data is following a very comprehensive and detailed process for the purification of relevant data. The Scopus database is used for data selection on digital education 4.0; after removing duplication and irrelevant literature, 47 studies are classified into three categories. All the classes are evaluated according to the segment, procedure, and methodology adopted by the authors. Based on those articles, the evaluation of research findings, conclusions, and recommendations are discussed for future researchers.

The current study evaluates that education 4.0 is drastically changing the world of education. Researchers are pointing out the gap between the skills available and the skills required to meet the education sector's needs. The industries are gradually looking for graduates; they can deal with industry revolution 4.0 [40]. Education reforms are a significant element for the educational transformation; digital technologies depend on the governments and policymakers. The adaptation of innovative technologies is difficult for individuals and educational institutes. The impact of education 4.0 is holistically essential for society [41]. Some of the researchers in the current study discuss the importance of teachers' and students' adaptability of digital technologies for educational purposes. The findings show that teachers are less attracted to adapt and learn new educational methods; simultaneously, students are positive toward learning new technologies. Individuals and organizations are unwilling to learn new educational technologies and digitalization; they are not part of the Future's new digital world. That is transforming into digitalization; educational structures are moving into technological devices.

\subsection{Recommendations for future work}

This study presented the evidence map has confirmed previous research on education 4.0 nexus, it has also clarified several areas that further research is encouraged to address. In the current review, only one database is used to extract the data, while 
many other reputed databases are available for literature. Future researchers can use these resources for more netter mapping of literature.

\section{$5 \quad$ References}

[1] M. Bond, K. Buntins, S. Bedenlier, O. Zawacki-Richter, and M. Kerres, "Mapping research in student engagement and educational technology in higher education: a systematic evidence map," International Journal of Educational Technology in Higher Education, vol. 17, no. 1. Springer, Dec. 2020, https://doi.org/10.1186/s41239-019-0176-8

[2] A. M. Ronchi and A. M. Ronchi, "e-Learning: How Teaching and Training Methods Changed in the Last 20 Years," in e-Services, Springer International Publishing, 2019, pp. 69-113. https://doi.org/10.1007/978-3-030-01842-9 2

[3] J. Jung, "The fourth industrial revolution, knowledge production and higher education in South Korea," J. High. Educ. Policy Manag., vol. 42, no. 2, pp. 134-156, Mar. 2020, https://doi.org/10.1080/1360080x.2019.1660047

[4] J. Wu, S. Guo, H. Huang, W. Liu, and Y. Xiang, "Information and communications technologies for sustainable development goals: State-of-the-art, needs and perspectives," IEEE Commun. Surv. Tutorials, vol. 20, no. 3, pp. 2389-2406, Jul. 2018, https://doi.org/10.1109/comst.2018.2812301

[5] N. Khan and M. I. Qureshi, "A systematic literature review on online medical services in Malaysia," Int. J. online Biomed. Eng., vol. 16, no. 6, pp. 107-118, 2020, https://doi.org/10.3991/ijoe.v16i06.13573

[6] R. Eglash, M. Lachney, W. Babbitt, A. Bennett, M. Reinhardt, and J. Davis, "Decolonizing education with Anishinaabe arcs: generative STEM as a path to indigenous futurity," Educ. Technol. Res. Dev., vol. 68, no. 3, pp. 1569-1593, Jun. 2020, https://doi.org/10.1007/ s11423-019-09728-6

[7] A. Kim, "Conflict of Institutions: Foreign Portfolio Investment as an Impetus for Legal Education Reform in Korea," Aug. 2020.

[8] J. H. Roodt and H. Koen, "A Review of Hurdles to Adopting Industry 4.0 in Developing Countries," INCOSE Int. Symp., vol. 30, no. 1, pp. 1079-1092, Jul. 2020, https://doi.org/10.1002/j.2334-5837.2020.00773.x

[9] M. Brundage et al., "The malicious use of artificial intelligence: Forecasting, prevention, and mitigation," arXiv. arXiv, Feb. 2018.

[10] D. Moher et al., "Preferred reporting items for systematic reviews and meta-analyses: The PRISMA statement," PLoS Medicine, vol. 6, no. 7. Public Library of Science, p. e1000097, Jul. 2009, https://doi.org/10.1371/journal.pmed.1000097

[11] F. Craveiro, J. P. Duarte, H. Bartolo, and P. J. Bartolo, "Additive manufacturing as an enabling technology for digital construction: A perspective on Construction 4.0," 2019, https://doi.org/10.1016/j.autcon.2019.03.011

[12] E. B. Gerasimova, A. A. Kurashova, M. V. Tipalina, M. V. Bulatenko, and N. V. Tarasova, "New state standards of higher education for training of digital personnel in the conditions of Industry 4.0," Horiz., vol. 27, no. 3-4, pp. 199-205, Oct. 2019, https://doi.org/10. 1108/oth-07-2019-0043

[13] C. Rosenzweig et al., "Developing coastal adaptation to climate change in the New York City infrastructure-shed: Process, approach, tools, and strategies," Clim. Change, vol. 106, no. 1, pp. 93-127, May 2011, https://doi.org/10.1007/s10584-010-0002-8 
[14] A. Pérez et al., “No 主観的健康感を中心とした在宅高齢者における 健康関連指標に 関する共分散構造分析Title,” BMC Public Health, vol. 5, no. 1, pp. 1-8, 2017.

[15] N. Hrtoňová, J. Kohout, L. Rohlíková, and J. Zounek, "Factors influencing acceptance of e-learning by teachers in the Czech Republic," Comput. Human Behav., vol. 51, pp. 873879, Oct. 2015, https://doi.org/10.1016/j.chb.2014.11.018

[16] F. Zeehan, R. A. Alias, and Z. Tasir, "Discovering Digital Technology Training Challenges for Future-Ready Educator: A Preliminary Study from Trainer Perspective," Univers. J. Educ. Res., vol. 8, no. 3A, pp. 12-23, 2020, https://doi.org/10.13189/ujer.2020.081 $\underline{403}$

[17] S. W. B. Tan, P. K. Naraharisetti, S. K. Chin, and L. Y. Lee, "Simple Visual-Aided Automated Titration Using the Python Programming Language," J. Chem. Educ., vol. 97, no. 3, pp. 850-854, Mar. 2020, https://doi.org/10.1021/acs.jchemed.9b00802

[18] M. Hernandez-de-Menendez, C. A. Escobar Díaz, and R. Morales-Menendez, "Engineering education for smart 4.0 technology: a review," Int. J. Interact. Des. Manuf., vol. 14, no. 3, pp. 789-803, Sep. 2020, https://doi.org/10.1007/s12008-020-00672-x

[19] A. Hariharasudan and S. Kot, "A scoping review on Digital English and Education 4.0 for Industry 4.0," Soc. Sci., vol. 7, no. 11, p. 227, Nov. 2018, https://doi.org/10.3390/ $\underline{\text { socsci7110227 }}$

[20] L. Farrell, T. Newman, and C. Corbel, "Literacy and the workplace revolution: a social view of literate work practices in Industry 4.0," Discourse, 2020, doi: $\underline{10.1080 / 01596306.2020 .}$ 1753016.

[21] J. S. Twyman, "Envisioning education 3.0: The fusion of behavior analysis, learning science and technology," Rev. Mex. Anal. la Conduct., vol. 40, no. 2, pp. 20-38, 2014, https://doi.org/10.5514/rmac.v40.i2.63663

[22] L. Molin, A. L. Godhe, and A. Lantz-Andersson, "Instructional challenges of incorporating aspects of critical literacy work in digitalised classrooms," Cogent Educ., vol. 5, no. 1, pp. 1-17, Jan. 2018, https://doi.org/10.1080/2331186x.2018.1516499

[23] World Economic Forum, "The Global Competitiveness Report 2009-2010 | World Economic Forum - The Global Competitiveness Report 2009-2010,” 2009.

[24] T. L. Vu Anh and T. Le Quoc, "Development orientation for higher education training programme of mechanical engineering in industrial revolution 4.0: A perspective in $\mathrm{Vi}$ etnam,” J. Mech. Eng. Res. Dev., vol. 42, no. 1, pp. 71-73, 2019, https://doi.org/10.26480/ jmerd.01.2019.71.73

[25] N. Azah Mansor, N. Abdullah, and H. Abd Rahman, "Towards electronic learning features in education 4.0 environment: literature study,” Indones. J. Electr. Eng. Comput. Sci., vol. 19, no. 1, p. 442, 2020, https://doi.org/10.11591/ijeecs.v19.i1.pp442-450

[26] M. I. Qureshi, N. Khan, S. Qayyum, S. Malik, H. S. Sanil, and T. Ramayah, "Classifications of sustainable manufacturing practices in ASEAN region: A systematic review and bibliometric analysis of the past decade of research," Sustainability (Switzerland), vol. 12, no. 21. MDPI AG, pp. 1-19, Oct. 2020, https://doi.org/10.3390/su12218950

[27] S. Khan, "Modern Internet of Things as a Challenge for Higher Education Article Cloud Computing Utilization For E-Learning Pharmaceutical System View project Modern Internet of Things as a Challenge for Higher Education," 2018.

[28] F. Pires, J. Barbosa, and P. Leitao, "Quo Vadis Industry 4.0: An Overview Based on Scientific Publications Analytics," in IEEE International Symposium on Industrial Electronics, Aug. 2018, vol. 2018-June, pp. 663-668, https://doi.org/10.1109/isie.2018.8433 $\underline{868}$ 
[29] B. Goswami, A. Jain, and B. Koner, "Evaluation of brainstorming session as a teachinglearning tool among postgraduate medical biochemistry students," Int. J. Appl. Basic Med. Res., vol. 7, no. 5, p. 15, 2017, https://doi.org/10.4103/ijabmr.ijabmr_191_17

[30] R. A. Ramirez-Mendoza, R. Morales-Menendez, H. Iqbal, and R. Parra-Saldivar, "Engineering Education 4.0:-proposal for a new Curricula," in IEEE Global Engineering Education Conference, EDUCON, May 2018, vol. 2018-April, pp. 1273-1282, https://doi.org/10. 1109/educon.2018.8363376

[31] R. Motschnig, D. Pfeiffer, A. Gawin, P. Gawin, M. Steiner, and L. Streli, "Enhancing stanford design thinking for kids with digital technologies a participatory action research approach to challenge-based learning," in Proceedings - Frontiers in Education Conference, FIE, 2019, vol. 2018-Octob, https://doi.org/10.1109/fie.2018.8658859

[32] N. Durakbasa, G. Bas, and J. Bauer, "Implementing Education Vision in the Context of Industry 4.0," in IOP Conference Series: Materials Science and Engineering, Nov. 2018, vol. 448, no. 1, https://doi.org/10.1088/1757-899x/448/1/012045

[33] M. R. Safiullin and E. M. Akhmetshin, "Digital transformation of a university as a factor of ensuring its competitiveness," Int. J. Eng. Adv. Technol., vol. 9, no. 1, pp. 7387-7390, 2019, doi: 10.35940/ijeat.A3097.109119.

[34] A. A. Ismail and R. Hassan, "Technical competencies in digital technology towards industrial revolution 4.0," J. Tech. Educ. Train., vol. 11, no. 3, pp. 55-62, 2019, doi: 10.30880/jtet.2019.11.03.008.

[35] M. J. Timms, K. Moyle, P. R. Weldon, and P. Mitchell, "Challenges in STEM learning in Australian schools. Policy Insights Issue 7,” May 2018.

[36] M. I. Qureshi, N. Khan, S. M. Ahmad Hassan Gillani, and H. Raza, "A systematic review of past decade of mobile learning: What we learned and where to go," Int. J. Interact. Mob. Technol., vol. 14, no. 6, pp. 67-81, Apr. 2020, https://doi.org/10.3991/ijim.v14i06. $\underline{13479}$

[37] D. J. Leiner, L. Kobilke, C. Rueß, and H. B. Brosius, "Functional domains of social media platforms: Structuring the uses of Facebook to better understand its gratifications," Comput. Human Behav., vol. 83, pp. 194-203, Jun. 2018, https://doi.org/10.1016/j.chb.2018. $\underline{01.042}$

[38] K. V. Vodenko and S. A. Lyausheva, "Science and education in the form 4.0: public policy and organization based on human and artificial intellectual capital," J. Intellect. Cap., vol. 21, no. 4, pp. 549-564, Apr. 2020, https://doi.org/10.1108/jic-11-2019-0274

[39] N. Sirotkina, V. Mishchenko, A. Greshonkov, S. Kaminskiy, and A. Kazartseva, "Challenges and opportunities of human potential in the conditions of technological breakthrough," in Proceedings of the 33rd International Business Information Management Association Conference, IBIMA 2019: Education Excellence and Innovation Management through Vision 2020, 2019, pp. 7910-7918.

[40] D. Mourtzis, "Development of skills and competences in manufacturing towards education 4.0: A teaching factory approach," in Lecture Notes in Mechanical Engineering, vol. 0, no. 9783319895628, Pleiades Publishing, 2018, pp. 194-210. https://doi.org/10.1007/ 978-3-319-89563-5_15

[41] N. Hanna, "A role for the state in the digital age," Journal of Innovation and Entrepreneurship, vol. 7, no. 1. SpringerOpen, pp. 1-16, Dec. 2018, doi: 10.1186/s13731-018-0086-3 


\section{$6 \quad$ Authors}

Muhammad Imran Qureshi is working with Faculty of Technology Management and Technopreneurship, Universiti Teknikal Malaysia Melaka, Malaysia. Email: qureshi@utem.edu.my

Nohman Khan is with UniKL Business School Universiti Kuala Lumpur, Malaysia

Hamad Raza works for Azman Hashim International Business School (AHIBS), Universiti Teknologi Malaysia (UTM), 81310, Johor Bahru, Johor, Malaysia

Amina Imran is aFaculty of Technology Management \& Business, Universiti Tun Hussein Onn Malaysia, Johor, Malaysia.

Fadillah Ismail is a Faculty of Technology Management \& Business, Universiti Tun Hussein Onn Malaysia, Johor, Malaysia. Email: fadillah@uthm.edu.my

Article submitted 2020-12-04. Resubmitted 2021-01-09. Final acceptance 2021-01-12. Final version published as submitted by the authors. 